\title{
Public opinion on Reasons for Emigration
}

\author{
Boomika Imayavarthini.T, Sreeya B
}

\begin{abstract}
This paper centers around a conceivable impact of displacement on human capital development. Emigration on a higher comes back to expertise nation gives an impetus to put resources into human capital. The level of human capital arrangement in the source nation can accordingly be emphatically corresponded with the likelihood of displacement. Unexpectedly a flood in emigration can lead the source nation out of being worked on snare. The ramifications of the model for the combination debate are likewise discussed.Preferred resettlement goals among young people reflect pictures and generalizations of different nations that persistently develop in a huge number of neighborhood and worldwide talks and from solid encounters with other countries.The results bolster the model firmly in many regards. Both wage rates and business rates in the sending and in the accepting nations affected vacillations in migration. The short-run changes were driven to a great extent by varieties in work rates while the long-run level of migration was resolved generally by the relative wage. Convenient sampling method is used in this study to collect the sample.1860 samples are recorded .The independent variables used are gender,educational qualifications,monthly income. The dependent variables prefer setting in abroad,preference of aboard, reason for emigration.The statistics used are independent sample t,chi-square,Anova.The objective is to understand the reasons for emigration It is concluded that emigration is most major things in the world.The emigration is mainly due to higher income and good governance country
\end{abstract}

Key words : Emigration, demographers,vacillating,people ,aboard

\section{INTRODUCTION}

Emigration is the demonstration of leaving an occupant nation or spot of home with the purpose to settle somewhere else. On the other hand, migration portrays the development of individuals into one nation from another. Both are demonstrations of movement crosswise over national or other land boundaries.Demographers look at push and destroy factors for individuals to be pushed out of one spot and pulled in to another. There can be a longing to escape negative conditions, for example, deficiencies of land or employments, or out of line treatment. Individuals can be dismantled to the open doors accessible somewhere else. Escaping from abusive conditions, being an evacuees and

Manuscript published on November 30, 2019.

* Correspondence Author

Boomika Imayavarthini.T*, B.B.A,L.L.B (HONS) $1^{\text {st }}$ year , Saveetha School of Law, Saveetha Institute of Medical and Technical Sciences (SIMATS), Tamilnadu, India. (Email: boomika2612@gmail.com)

Dr. Sreeya B, Associate Professor, Saveetha School of Law, Saveetha Institute of Medical and Technical Sciences (SIMATS), Tamilnadu, India. (Email: sreeyab.ssl@saveetha.com)

(C) The Authors. Published by Blue Eyes Intelligence Engineering and Sciences Publication (BEIESP). This is an open access article under the CC-BY-NC-ND license http://creativecommons.org/licenses/by-nc-nd/4.0/ looking for haven to get outcast status in a remote nation, may prompt lasting emigration.Forced uprooting alludes to bunches that are compelled to relinquish their local nation, for example, by authorized populace move or the danger of ethnic purging.The aim of the study to know about the public opinion on reason for emigration.

\section{OBJECTIVES}

- To understand the reason for emigration

- To analyse whether there is a difference between opinion on settling in abroad and the gender

- To know the difference between the reason for emigration among the monthly income groups

- To analyse the association between group of people preferring aboard and education qualifications

\section{LITERATURE REVIEW}

.Esme Fuller-Thomson, Sarah Brennenstuhl, Rachel Cooper, Diana Kuh( 2015) The author inspected that vagrants to high-paying nations have lower paces of bleakness and mortality than non-transients, controlling for financial position. Travelers would be advised to youth wellbeing higher youth financial position and better youth subjective capacity at age 8 than non-wanderers.Heisler (1985)The author inspected that Migration makes a few chances, yet a lot more difficulties for center administration in Latin America. It merits more noteworthy consideration from lodge specialists. The author presumed that individuals of India were enormous skilled to gaming the acknowledgment.Achotegui (2005)The author inspected that During the most recent years, worker populaces have been living in hard conditions. To million individuals, movement is turning into a procedure with a significant level of pressure outperforming the person limit of adjustment. In this article, the author proposes a connection between the significant level of pressure endured by the settlers and their introduction of psychopathological indications.S Irudaya Rajan(2004)This author analyzed that financial and social outcomes of work movement from Kerala to the Gulf Region. In India, Kerala is both the significant wellspring of vagrant laborers and the essential beneficiary of laborers' settlements.Xiang Biao (2016)) The author analyzed ims to give an extensive review of the approaches sought after by the People's Republic of China in regards to the emigration of Chinese nationals. The majority of the accessible writing on relocation the executives has concentrated on getting nations.GARY HOWELLS( 2003)The author found that Nineteenth-century helped emigration has for quite some time been related with the expression 'scooping out beggar'.

Published By:

Blue Eyes Intelligence Engineering and Sciences Publication (BEIESP) 
This view is tested by the activities and frames of mind of the patrons of ward helped emigration who put extensive time and vitality in supporting the emigration of their poor. Sloan,Volker Meier(2015)The author investigated that both the arrangement of since a long time ago run movement motivators and the outcomes of a system change from "autarky" to "free relocation" in a covering ages structure with two nations..Duleep HO (1994)The author found that general suspicions identified with the level and timing of emigration in the life of individuals. Past patterns in emigration and components that may influence present and future degrees of emigration are depicted. The article likewise displays hypothetical desires and exact proof concerning the planning of emigration.

\section{METHODOLOGY}

The study found out that Descriptive research on Reasons for Emigration. convenient sampling method is used in this study to collect the sample.1860 samples are recorded .The independent variables used are gender,educational qualifications,monthly income .The dependent variables prefer setting abroad, preference of aboard, reason for emigration.The statistics used are independent sample t,chi-square,Anova.

\section{ANALYSIS AND DISCUSSION \& RESULTS}

Null hypothesis (H0): There is no significant difference between settling in abroad and the gender

Alternative Hypothesis (H1): There is a significant difference between settling in abroad and the gender

Table: 1 Settling in abroad and the gender

\begin{tabular}{|l|l|l|l|l|}
\hline Gender & $\mathrm{N}$ & Mean & $\begin{array}{l}\text { std.Devi } \\
\text { ation }\end{array}$ & $\begin{array}{l}\text { std.Error } \\
\text { Mean }\end{array}$ \\
\hline Male & 1106 & 1.57 & .495 & .015 \\
Female & 754 & 1.52 & .500 & .018 \\
\hline
\end{tabular}

source : primary data

Table 2: Independent sample t test:Settling in abroad and the gender

\begin{tabular}{|l|l|l|l|}
\hline & value & df & p-value \\
\hline $\begin{array}{l}\text { Independent } \\
\text { sample t test }\end{array}$ & 2.178 & 1858 & .030 \\
\hline
\end{tabular}

source: primary data

Interpretation Using Independent sample t test, it was found that $\mathrm{p}$ esteem is under 0.05 , which shows that the null hypothesis is rejected. Hence, there is a significant difference between settling in abroad and the gender

Null hypothesis ( H0): There is no significant association between group of people preferring aboard and educational qualification

Alternative hypothesis ( H1): There is significant association between group of people preferring aboard and educational qualification

Table 3:Cross tabulation - group of people prefer abroad and educational qualifications

\begin{tabular}{|c|c|c|c|c|}
\hline \multirow{3}{*}{\multicolumn{2}{|c|}{ Cross tabulation }} & peopl & fer $a b$ & 1 and \\
\hline & & \multicolumn{2}{|c|}{ people prefer abroad } & \multirow{2}{*}{$\begin{array}{l}\text { Tota } \\
\text { l }\end{array}$} \\
\hline & & Rich & middle & \\
\hline \multirow{5}{*}{$\begin{array}{l}\text { (v) Educational } \\
\text { Qualification }\end{array}$} & Primary & 80 & 77 & 158 \\
\hline & $\begin{array}{l}\text { High } \\
\text { School }\end{array}$ & 285 & 86 & 387 \\
\hline & $\begin{array}{l}\text { Higher } \\
\text { Secondary }\end{array}$ & 61 & 573 & 804 \\
\hline & $\begin{array}{l}\text { Degree and } \\
\text { above }\end{array}$ & 124 & 233 & 467 \\
\hline & Illiterate & 1 & 38 & 44 \\
\hline \multicolumn{2}{|l|}{ Total } & 551 & 1007 & 1860 \\
\hline
\end{tabular}

Source: primary data

Table 4:Chi Square test - group of people preferring abroad and educational qualification

\begin{tabular}{|l|l|l|l|}
\hline & value & df & p-value \\
\hline $\begin{array}{l}\text { Pearson } \\
\text { chi- square }\end{array}$ & 321.456 & 12 & 0.0000 \\
\hline
\end{tabular}

Source: primary data

\section{Interpretation}

Using Chi square test, it was found that p esteem is under 0.05 , which shows that the null hypothesis is rejected.Hence, there is significant association between group of people preferring aboard and educational qualifications.

Null hypothesis ( H0) : There is no significant difference between the reason for emigration among the monthly income groups

Alternative hypothesis ( H1): There is a significant difference between the reason for emigration among the monthly income groups

Table 5: ANOVA for Reasons for emigration and monthly income

\begin{tabular}{|c|c|c|c|c|c|c|}
\hline \multicolumn{7}{|l|}{ ANOVA } \\
\hline & & Sum of Squares & df & Mean Square & $F$ & Sig. \\
\hline Higher income & Between Groups & 94.927 & 3 & 31.642 & 22.374 & .000 \\
\hline
\end{tabular}




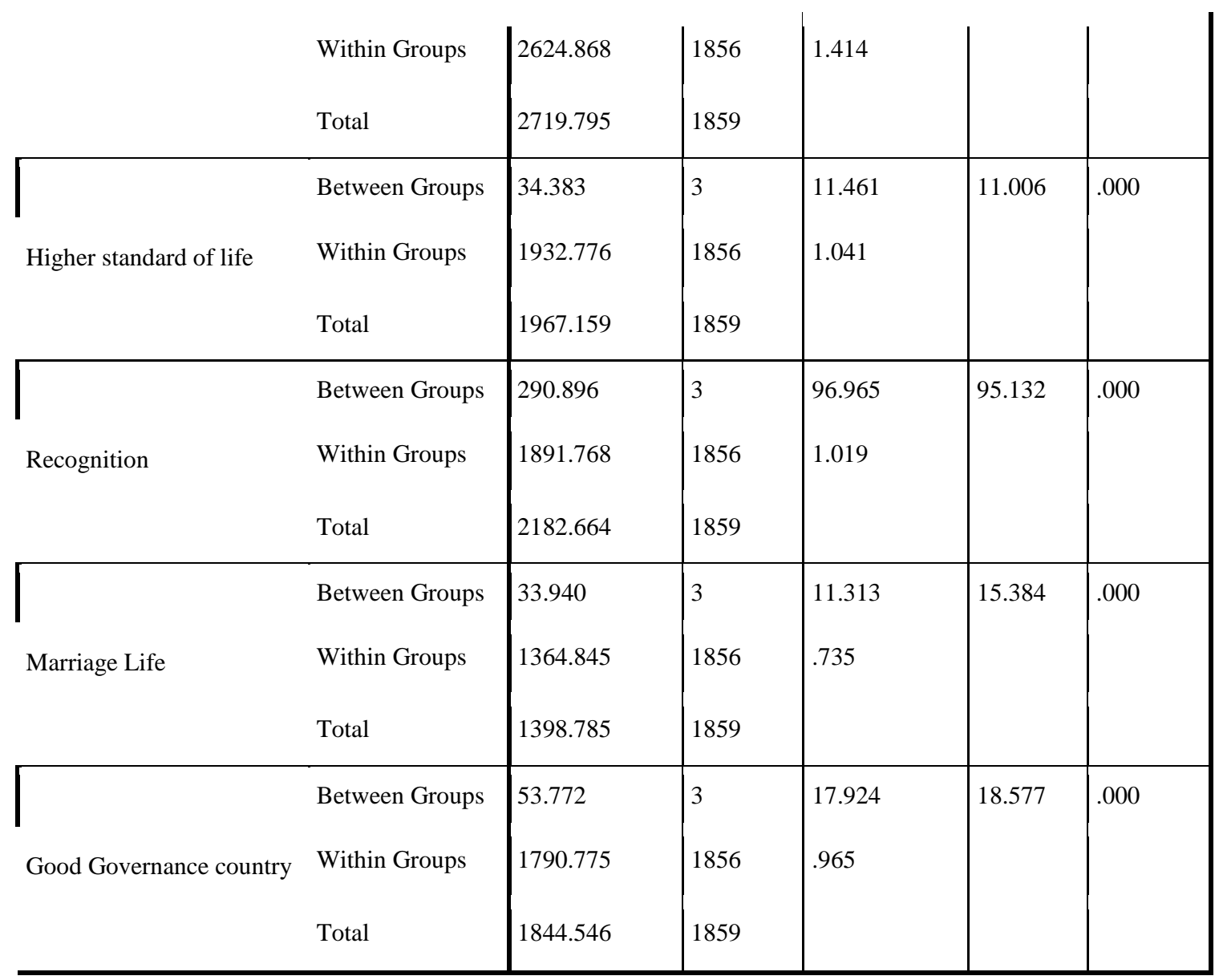

source: primary data

\section{Interpretation:}

Using ANOVA it was analysed whether the level of agreeability regarding reason for emigration on monthly income groups. Since the $\mathrm{p}$ value of all the reasons are less than 0.05, it was found that there is significant difference the reason for emigration among the monthly income groups

\section{ACKNOWLEDGEMENT}

I sincerely thanks Dr.sreeya B ,associate professor for giving me the opportunity to this research.I also thank my friends and family for helping me in doing the survey conducted for the research

\section{CONCLUSION}

The above investigation demonstrates that the life of the general population have a tendency to be better monetarily after resettlement just based on nourishment adequacy, economic well being, propensities and utilization designs. However, this is a marvel, or, in other words to proceed for quite a while. The high pay created is a direct result of the convertibility of remote cash. movement has never been a simple undertaking. Factual sources might be missing, and notwithstanding when accessible, they are regularly opposing. For a considerable length of time governments, inquire about focuses and universal associations 'contended' for the meanings of relocation for their interests, which were frequently clashing.
With the ascent of illicit relocation, measurements have turned out to be like never before approximations, frequently a long way from the real world. Be that as it may, plainly relocation is an irreversible truth that will proceed with on account of the necessities of both southern and northern nations. Industrialized nations experiencing the third phase of the statistic change will require a modest work drive, while the southern nations should trade some portion of their childhood needing work.

\section{REFERENCES}

1. Achotegui, Joseba. 2005. "[Emigration in hard conditions: the Immigrant Syndrome with chronic and multiple stress (Ulysses' Syndrome)]." Vertex 16 (60): 105-13.

2. Brennenstuhl, Sarah, and Esme Fuller-Thomson. 2015. "The Painful Legacy of Childhood Violence: Migraine Headaches Among Adult Survivors of Adverse Childhood Experiences." Headache: The Journal of Head and Face Pain 55 (7): 973-83.

3. Duleep, H. O. 1994. "Social Security and the Emigration of Immigrants." Social Security Bulletin 57 (1): 37-52.

4. Heisler, Barbara Schmitter. 1985. "Sending Countries and the Politics of Emigration and Destination." The International Migration Review 19 (3): 469.

5. Howells, Gary. 2000. "Emigration and the New Poor Law: The Norfolk Emigration Fever of 1836." Rural History: Economy, Society Culture 11 (02): 145.

6. Irudaya Rajan, S. 2016. India Migration Report 2016: Gulf Migration. Routledge.

7. Sloan, Michael K., and Philip S. Morrison. 2015. "The Post-Move Satisfaction of Internal Migrants." Migration Studies 4 (1): 97-115.

8. Xiang, Biao. 2016. "Emigration Trends and Policies in China." In Spotlight on China, 247-67. 


\section{Public opinion on Reasons for Emigration}

\section{RESULTS}

100\% Completed: $100 \%$ Checked

$0 \%$

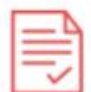

Sentence Wise Result

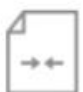

Matched Sources

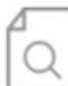

Document View

UNIQUE This paper centers around a conceivable impact of displacement on hu...

UNIQUE Emigration on a higher comes back to expertise nation gives an impetu...

UNIQUE The level of human capital arrangement in the source nation can accor...

UNIQUE Unexpectedly a flood in emigration can lead the source nation out of a...

UNIQUE The ramifications of the model for the combination debate are likewise..

UNIQUE huge number of neighborhood and worldwide talks and from solid enc...

UNIQUE Both wage rates and business rates in the sending and in the accepting ...

UNIQUE The short-run changes were driven to a great extent by varieties in wor...

UNIQUE is used in this study to collect the sample.1860 samples are recorded.T...

UNIQUE The dependent variables prefer setting in abroad, preference of aboard... 


\section{RESULTS}

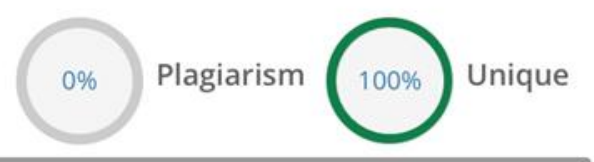

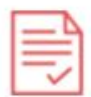

Sentence Wise Result

\section{Matched Sources}

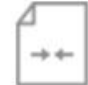

Document View
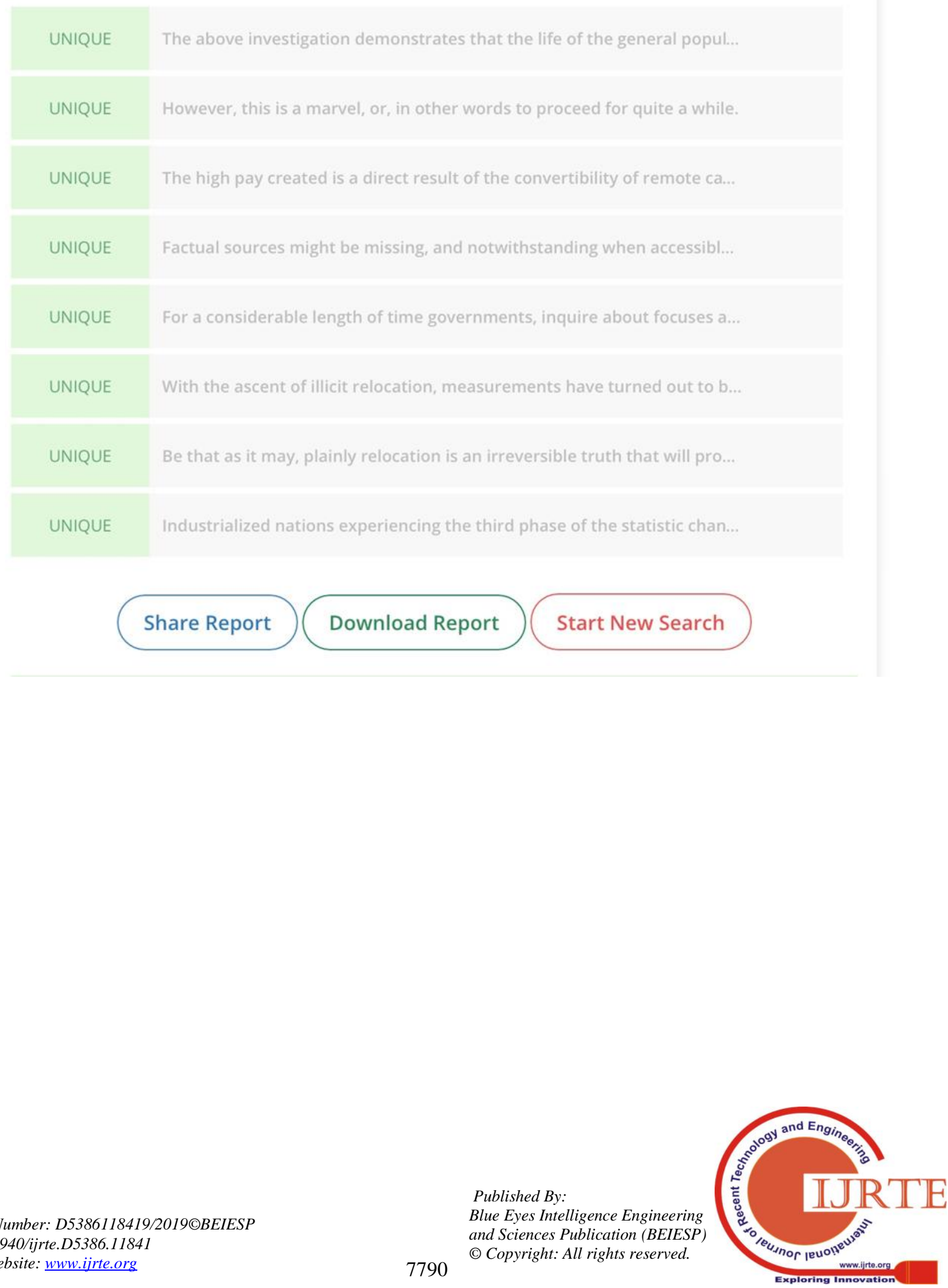